\title{
Comparison of femur intertrochanteric fracture fixation with hemiarthroplasty and proximal femoral nail systems
}

\author{
Gökay Görmeli, M.D., ${ }^{1}$ Mehmet Fatih Korkmaz, M.D., ${ }^{1}$ Cemile Ayşe Görmeli, M.D., ${ }^{2}$ \\ Cihan Adanaş, M.D., ${ }^{3}$ Turgay Karataş, M.D., ${ }^{4}$ Sezai Aykın Şimşek, M.D. ${ }^{5}$

\begin{abstract}
1Department of Orthopedics and Traumatology, Inonu University Faculty of Medicine, Turgut Özal Medical Center, Malatya ${ }^{2}$ Department of Radiology, Inonu University Faculty of Medicine, Turgut Özal Medical Center, Malatya

${ }^{3}$ Department of Orthopedics and Traumatology, Van Training and Research Hospital, Van

${ }^{4}$ Department of General Surgery, Malatya State Hospital, Malatya

${ }^{5}$ Department of Orthopedics and Traumatology, American Hospital, Istanbul
\end{abstract}

\begin{abstract}
BACKGROUND: The aim of this study was to compare the outcomes of intertrochanteric femur fractures treated with proximal femoral nail (PFN) and bipolar hemiarthroplasty (BPH) in elderly patients.

METHODS: A total of one hundred and forty-three patients with intertrochanteric femur fractures treated surgically between January 2008 and January 2012 were included into the study. Patient demographics, type of fracture according to Association for Osteosynthesis/Association for the Study of Internal Fixation (AO/ASIF) classification, and the American Society of Anesthesiologists (ASA) classification system scores; type of surgical procedure (BPH or PFN), operative details, complications and follow-up scores (Harris Hip Score [HHS]; Mean Mobility Score [MMS]) were recorded.
\end{abstract}

RESULTS: The preoperative characteristics of the patients in both PFN and BPH groups were similar. BPH had higher operation times, blood loss in operation and mortality rates $(p<0.005)$. Reoperation times were higher in PFN group $(p<0.005)$. There were no differences with regard to the HHS and the reduction in MMS at the last follow-up with a 30.4 (I0.9) months follow-up ( $p>0.05$ ).

CONCLUSION: Although both PFN and BPH had satisfactory outcomes in surgically treated patients with intertrochanteric femur fractures, we recommend intertrochanteric femur fractures in the elderly tobe treated with PFN; which is an effective and appropriate treatment modality with less surgery related trauma and lower mortality rates.

Key words: Bipolar hemiarthroplasty; femur intertrochanteric fracture; Harris Hip Score; mortality; proximal femoral nail.

\section{INTRODUCTION}

The incidence of hip fractures is rising due to inreasing life expectancy in the elderly population. Also, mortality after femur proximal femur fracture is increasing with a I-year mortality rate of 14 to $36 \% .^{[1,2]}$ One of the major problems with these fractures is patients' return to their preoperative period level of activity and independence in carrying out daily

Address for correspondence: Mehmet Fatih Korkmaz, M.D. İnönü Üniversitesi Tıp Fakültesi, Turgut Özal Tıp Merkezi, Ortopedi ve Travmatoloji Anabilim Dalı, Malatya, Turkey

Tel: +90 422 - 34l 0660 E-mail: fatih.korkmaz@inonu.edu.tr

Qucik Response Code Ulus Travma Acil Cerrahi Derg

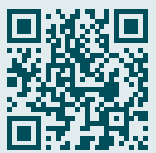

20I5;2I(6):503-508

doi: $10.5505 /$ tites.2015.96166

Copyright 2015

TJTES routines. ${ }^{[3]} 50 \%$ of these patients require assistance in their daily living activities, and $25 \%$ need to receive long-term care after treatment. ${ }^{[4]}$

Due to problems caused by these fractures and an increase in the number of the elderly population leading to a significant increase in the incidence of these fractures, it is absolutely necessary to use an effective and appropriate treatment modality for such patients. Due to their poor bone quality, it is very difficult to achieve and maintain a stable fixation in elderly patients. Many treatment methods have been used for the reduction of intertrochanteric fractures, including dynamic hip screw (DHS), proximal femoral nail (PFN), unipolar and bipolar hemiarthroplasty and external fixation. However, it is difficult to achieve and maintain a stable fixation in elderly patients due to their poor bone quality. ${ }^{[5,6]}$ Early mobilization and prompt return to prefracture activity levels are the main goals of surgery. The treatment of this fracture remains a challenge to the surgeon, and there is still controversy about 
the ideal treatment modality of hip fractures in elderly patients.

Therefore, the present study was undertaken to compare outcomes of reduction of intertrochanteric fractures using internal fixation with the use of PFN and bipolar hemiarthroplasty $(\mathrm{BPH})$ in elderly patients.

\section{MATERIALS AND METHODS}

This retrospective study was approved by the Local Institutional Ethics Board in accordance with the standards of the Declaration of Helsinki. Patients with intertrochanteric femur fractures treated surgically between January 2008 and January 2012 were included into the study. Exclusion criteria consisted of a history of osteoarthritis in the hip joint, pathologic fractures, bilateral fractures, age less than 65 years, rheumatoid arthritis, chronic renal failure, fractures secondary to tumour, Paget's disease or metabolic bone disease.

Patients' clinical and radiographical features were evaluated at initial presentation, surgery and last follow-up, retrospectively. Collected data were demographics, time between injury to surgery, type of fracture according to AO/ASIF classification, and the American Society of Anesthesiologists (ASA) physical status classification (ASA grade), type of surgical procedure (osteosynthesis with a proximal femoral nail (Veronail $^{\circledR}$; Orthofix,SRL,Verona,Italy) or cemented or cementhless bipolar hemiarthroplasty (Spectron ${ }^{\circledR}$ or Echelon ${ }^{\circledR}$ Smith \& Nephew, Memphis, TN, USA; Biomet Inc. Warsaw, IN, USA; Ortopro ${ }^{\circledR}$,Ortopro Tibbi Aletler, Izmir, Turkey); duration of surgery, blood transfusion, and complications.

All operations were performed by the same group of experienced surgeons. In all cases, antithrombotic prophylaxis was given using low molecular weight heparin (Fraxiparine ${ }^{\circledR}$; GlaxoSmithKline, Brentford, UK) and antibiotic prophylaxis was provided. Anteroposterior and lateral radiographs were obtained 24-72 hours postoperatively, and analyzed for reduction and position of the implant.

For patients treated with PFN, the patients were mobilized on the first postoperative day. Partial weight bearing, as tolerated, or restricted weight bearing was allowed according to the surgeon's recommendation on the day following surgery. Full-weight bearing was allowed at 4th week for patients treated with PFN while full weight bearing was allowed in the first postoperative day for patients treated with BPH. Complications were classified as varus collapse, implant related problems (lateral sliding or cut out), secondary fractures, infection (deep or superficial), hip dislocation, non-union and systemic problems such as pulmonary embolism, cardiac ischemia, pneumonia, and urinary tract infection.

Patients were called back for a last follow-up. Thirty-six pa- tients from the PFN group and 43 patients from the BPH group admitted to the clinic for the last follow-up. Eleven of the patients were dead, 24 of them were living at an another city, 15 of them refused to admit to the clinic and the remaining 14 patients could not be reached. Clinical evaluation was made using the Mean mobility score (MMS) and Harris hip scoring system (HHS), which considers pain, walking capacity, and physical examination findings. ${ }^{[7]}$

\section{Statistical Evaluation}

The data were expressed as mean (standard deviation [SD]) depending upon overall variable distribution. Normality was assessed using Shapiro Wilk test. Qualitative data were analyzed with Pearson chi-square test. The data were compared through paired samples $t$ test and unpaired samples $t$ test between the groups. Correlations were estimated Spearman's rho as appropriate. $\mathrm{P}<0.05$ values were considered as significant. IBM SPSS statistics version 22.0 for Windows was used for statistical analyses.

\section{RESULTS}

A total of one hundred and forty-three patients meeting our study criteria comprised our study population. There was no significant difference between the PFN and BPH group in terms of demographic data, preexisting comorbidities, preoperative MMS, fracture type, ASA classification, and mean time from injury to surgery (Table I).

Significantly higher results were achieved in terms of operation times in minutes and blood loss and the number of patients needing blood transfusion was higher in the $\mathrm{BPH}$ group than in the PFN group $(p<0.005)$. Operative details are shown in Table 2.

Details of postoperative complications are shown in Table 3. PFN group has significantly higher reoperation times and $\mathrm{BPH}$ group has significantly higher one-year mortality rates $(p<0.05)$. None of the differences between the two groups was statistically significant in other parameters $(p>0.05)$. Superficial wound infection is defined as infection of the wound, in which there is no evidence that the infection extends to the site of the implant, occurred in five patients in the $\mathrm{BPH}$ group and in four in the PFN group. Deep wound infection, defined as infection around the implant, occurred in two patients in the hemiarthroplasty group and treated successfully with antibiotherapies. There was no dislocation in the BPH group. In one case, fracture occurred below the implant and was fixated with plate and screws. In two patients, haematoma occurred and a successful drainage was performed with no further complications. In the PFN group, there was ectopic new bone formation at the insertion point of stabilization and compression screw in only one patient without affecting the patient's condition. Revision surgery (hemiarthroplasty) was needed due to pseudoarthrosis in four and cut-out of the 
Table I. Preoperative data of the patients

Proximal femoral nail group

Number of patients*

Mean age in years (SD)

68

Number of men (\%)

Mean mobility score before fracture (SD)*

Mean ASA score (SD)*

Pre-existing cardiovascular disease (\%)*

Pre-existing respiratory disease (\%)

Mean time (hours) from injury to surgery (SD)*

Fracture classification*
3.I A.I (\%)
25 (36.7)
$33(48.5)$
3.I A.2 (\%)
7 (10.2)

75

$77.4(8.4)$

$32(42.6)$

$4.1(1.7)$

$2.77(0.88)$

$19(28.3)$

$12(16)$

$25.4(9.3)$

$30(40)$

$37(49.3)$

8 (10.6)

"No significant difference between proximal femoral nail and bipolar hemiarthroplasty groups $(p>0.05)$.

Table 2. Operative details

\begin{tabular}{lccc}
\hline & Proximal femoral nail group & Bipolar hemiarthroplasty group & $\mathbf{p}$ \\
\hline Number of patients & 68 & 75 & $>0.05$ \\
Operation with spinal anaesthesia (\%) & $46(67.6)$ & $54(75)$ & $>0.05$ \\
Mean (SD) operation time in minutes & $32.4(7.1)$ & $48.7(10.2)$ & $<0.005$ \\
Intraoperative blood loss in ml & $30.6(12.5)$ & $136.5(34.2)$ & $<0.005$ \\
Number of patients transfused (\%) & $6(8.8)$ & 4 I (54.6) & $<0.005$ \\
\hline
\end{tabular}

Table 3. Postoperative complications and mortality rates

\begin{tabular}{|c|c|c|}
\hline & Proximal femoral nail group & Bipolar hemiarthroplasty group \\
\hline Superficial wound infection ${ }^{a}$ & 5 & 4 \\
\hline Deep wound infection & - & 2 \\
\hline Pressure sores $^{\mathrm{a}}$ & 3 & 5 \\
\hline Pneumonia $^{a}$ & 1 & 0 \\
\hline Thromboembolic complications ${ }^{a}$ & 4 & 6 \\
\hline Neurological complication ${ }^{\mathrm{a}}$ & I & 2 \\
\hline Urinary tract infection ${ }^{\mathrm{a}}$ & 5 & 3 \\
\hline Wound haematoma requiring drainage & - & 2 \\
\hline Reoperation ${ }^{\mathrm{b}}$ & $8(11.7)$ & $2(2.6)$ \\
\hline Number of one year mortality (\%) & $6(8.8)$ & II (14.6) \\
\hline
\end{tabular}

a: No significant difference between proximal femoral nail and hemiarthroplasty groups $(p>0.05)$.

b: Significant difference between the groups $(p<0.05)$.

implant proximally in one, and avascular necrosis in three patients. One-year mortality was significantly higher in the $\mathrm{BPH}$ group (I9/75 [\%25.3]) than in the PFN group (8/68 [\%। .7]) $(<0.005)$.
Hospital stay was defined as the time from admission to discharge, and it was 3.8 (2.6) days for the PFN and 4.4 (2.9) days for the $\mathrm{BPH}$ group without any significant difference $(p<0.05)$. Also, there was no correlation between patients' 
Table 4. Follow-up scores

Proximal femoral nail group

Number of patients*

Length of follow-up months (SD)*

Harris Hip Score (SD)*

Mean reduction in mobility score (SD)*
36

$32.3(8.9)$

$79.7(7.8)$

$1.97(1.05)$
Hemiarthroplasty group

43

$29.6(10.3)$

$74.7(8.8)$

$2.14(1.14)$

*No significant difference between proximal femoral nail and bipolar hemiarthroplasty groups $(p>0.05)$

ages, ASA scores, operation time, intraoperative blood loss, and HHS ( $p>0.05)$.

Thirty-six patients in the PFN group (32.3 (8.9) months follow-up) and 43 patients in the BPH group (29.6 [10.3] months follow-up) were available for a last review. There was no significant difference between the groups in terms of HHS and mean reduction in MMS scores at the last follow-up. Table 4 gives details functional assessment of the patients.

\section{DISCUSSION}

The results of this study showed that both PFN and BPH are good treatment methods with similar satisfactory postoperative functional results. Significant shorter operation time, less blood-loss during operation and lower mortality rates seems to be the main advantages of internal fixation method with PFN while lower re-operation rate is the advantage of $\mathrm{BPH}$ for patients with intertrochanteric femur fractures.

Similar to our results, studies compiaring operative details have concluded that internal fixation is associated with shorter length of surgery, lower operative blood loss, and need for transfusions. ${ }^{[8-10]}$ The advantages of operative details are balanced with higher reoperation rates for internal fixation group. For the patients treated with PFN, reoperation reasons are redisplacement of the fractures, cut out of femoral head, implant breakage and nonunion. Dislocation may occur in patients treated with $\mathrm{BPH}$. Reoperation rates were $11 \%$ in a prospective study performed by Saudan et al.; ${ }^{[1]} \mid 4.8 \%$ in a randomized study performed by Pajarinen et al. ${ }^{[12]}$ Papasimos et al. ${ }^{[13]}$ found $12.5 \%$ reoperation rates as well. Our study showed high reoperation rates similar to the literature, and these patients were treated effectively by revision to bipolar hemiarthroplasty. Due to high osteoporosis rates in the elderly, we believe that internal fixation is appropriate for younger patients with proximal femur fractures. Hemiarthroplasty has a lower risk of secondary surgery for the elderly patients aged with a displaced intracapsular fracture.

The Cochrane review group has noted $28.6 \%$ pseudoarthrosis and $8.3 \%$ avascular necrosis with intracapsular femur fractures treated with internal fixation. ${ }^{[14]}$ Our results showed lower psedoarthrosis (7.3\%) and avascular necrosis rates
(4.4\%). This would be related to short time period from injury to surgery.

The choice of treatment methods in this study can be discussed. Studies have concluded that cementless hemiarthroplasty is preferred over cemented hemiarthroplasty because of reduced operation time and intra-operative blood loss and lower perioperative mortality rate. ${ }^{[15,16]}$ For the ideal internal fixation method, a meta-analysis performed by Zhang et al. hasconcluded that PFN may be a better choice than DHS in the treatment of intertrochanteric fractures. ${ }^{[17]}$ In a study of one hundred consecutive patients treated with PFN, Korkmaz et al. have concluded that PFN is a reliable fixation method for proximal femur fractures. ${ }^{[18]}$ In an another meta-analysis of randomized controlled trials, Huang et al. have concluded that PFN fixations shows the same effectiveness as DHS fixation. ${ }^{\left[{ }^{19]}\right.}$ According to these studies and metaanalyses, we performed cementless hemiarthroplasty for arthroplasty group and preferred PFN for the internal fixation method.

There were no statistically significant differences between the two groups in medical complications such as pressure sores, pneumonia, thromboembolic complications, and neurologic complications reported in a systematic review published by Parker et al. ${ }^{[20]}$ Moreover, length of hospital stay was similar between the internal fixation and hemiarthroplasty group. ${ }^{[9,21]}$ In our study, similar to the literature, we found no significant difference between the groups in terms of postoperative medical complications and length of hospital stay as shown in Table 3. Yet, our length of hospital stay was shorter than other studies. We discharged patients as soon as possible because of high infection risk related to diabetic wound patients treated by other surgeons in our clinic.

In our study, one-year mortality rates were significantly lower in the PFN group than the BHA group. The BHA group was slightly older than the PFN group (77.4 vs 76.2, $\mathrm{p}>0.05$ ) but this nonsignificant difference may not be related to higher mortality results as both groups had similar comorbidities and preoperative HHS and MMS. Karaman et al. have concluded many factors such as age, ASA score, preoperative comorbidities, type of anaesthesia affects the mortality rates but these are similar for the PFN and BPH group in our study. [22] Our findings are supported by Davison et al. and Kapicio- 
glu et al. who have reported higher mortality rates for arthroplasty group than internal fixation. ${ }^{[23,24]}$ On the contrary, other studies found no difference in mortality between internal fixation and arthroplasty. ${ }^{[25,26]}$

There are several limitations to this study. Retrospective nature, small patient group and mid-term follow-up are the main limitations. Long-term analyses were not possible because of short life expectancy in elderly patients. All procedures were not performed by the same surgeon which can lead to a variance in the results. However, usage of the same implants, operating room and fluoroscopy can be considered as advantages of this study.

In conclusion, both PFN and BPH appear to produce satisfactory outcomes in surgically treated proximal femur fractures. Both groups are associated with their own complications, but although internal fixation with PFN had higher reoperation rates, its less surgery related trauma and lower mortality rates are main advantages. Therefore, the clinician should choose the ideal method for each individual patient, but we think internal fixation may be the effective and appropriate treatment modality for elderly patients with extracapsular proximal femur fractures.

\section{Conflict of interest: None declared.}

\section{REFERENCES}

1. Vestergaard P, Rejnmark L, Mosekilde L. Has mortality after a hip fracture increased? J Am Geriatr Soc 2007;55:1720-6. CrossRef

2. Kesmezacar H, Ayhan E, Unlu MC, Seker A, Karaca S. Predictors of mortality in elderly patients with an intertrochanteric or a femoral neck fracture. J Trauma 2010;68:153-8. CrossRef

3. Blomfeldt R, Törnkvist H, Eriksson K, Söderqvist A, Ponzer S, Tidermark J. A randomised controlled trial comparing bipolar hemiarthroplasty with total hip replacement for displaced intracapsular fractures of the femoral neck in elderly patients. J Bone Joint Surg Br 2007;89:160-5.

4. Lu-Yao GL, Keller RB, Littenberg B, Wennberg JE. Outcomes after displaced fractures of the femoral neck. A meta-analysis of one hundred and six published reports. J Bone Joint Surg Am 1994;76:15-25.

5. Seyfettinoğlu F, Ersan O, Kovalak E, Duygun F, Ozsar B, Ateş Y. Fixation of femoral neck fractures with three screws: results and complications. Acta Orthop Traumatol Turc 2011;45:6-13. CrossRef

6. Bhandari M, Devereaux PJ, Swiontkowski MF, Tornetta P 3rd, Obremskey W, Koval KJ, et al. Internal fixation compared with arthroplasty for displaced fractures of the femoral neck. A meta-analysis. J Bone Joint Surg Am 2003;85:1673-81.

7. Harris WH. Traumatic arthritis of the hip after dislocation and acetabular fractures: treatment by mold arthroplasty. An end-result study using a new method of result evaluation. J Bone Joint Surg Am 1969;51:737-55.

8. Parker MJ, Khan RJ, Crawford J, Pryor GA. Hemiarthroplasty versus internal fixation for displaced intracapsular hip fractures in the elderly. A randomised trial of 455 patients. J Bone Joint Surg Br 2002;84:1150-5.

9. Parker MJ, Pryor GA. Internal fixation or arthroplasty for displaced cervical hip fractures in the elderly: a randomised controlled trial of $208 \mathrm{pa}-$ tients. Acta Orthop Scand 2000;71:440-6. CrossRef

10. Puolakka TJ, Laine HJ, Tarvainen T, Aho H. Thompson hemiarthro- plasty is superior to Ullevaal screws in treating displaced femoral neck fractures in patients over 75 years. A prospective randomized study with two-year follow-up. Ann Chir Gynaecol 2001;90:225-8.

11. Saudan M, Lübbeke A, Sadowski C, Riand N, Stern R, Hoffmeyer P. Pertrochanteric fractures: is there an advantage to an intramedullary nail?: a randomized, prospective study of 206 patients comparing the dynamic hip screw and proximal femoral nail. J Orthop Trauma 2002;16:386-93.

12. Pajarinen J, Lindahl J, Michelsson O, Savolainen V, Hirvensalo E. Pertrochanteric femoral fractures treated with a dynamic hip screw or a proximal femoral nail. A randomised study comparing post-operative rehabilitation. J Bone Joint Surg Br 2005;87:76-81.

13. Papasimos S, Koutsojannis CM, Panagopoulos A, Megas P, Lambiris E. A randomised comparison of AMBI, TGN and PFN for treatment of unstable trochanteric fractures. Arch Orthop Trauma Surg. 2005;125:462-8. CrossRef

14. Masson M, Parker MJ, Fleischer S. Internal fixation versus arthroplasty for intracapsular proximal femoral fractures in adults. Cochrane Database Syst Rev 2006;4:CD001708.

15. Ng ZD, Krishna L. Cemented versus cementless hemiarthroplasty for femoral neck fractures in the elderly. J Orthop Surg (Hong Kong) 2014;22:186-9.

16. Cankaya D, Ozkurt B, Tabak AY. Cemented calcar replacement versus cementless hemiarthroplasty for unstable intertrochanteric femur fractures in the elderly. Ulus Travma Acil Cerrahi Derg 2013;19:548-53. CrossRef

17. Zhang K, Zhang S, Yang J, Dong W, Wang S, Cheng Y, et al. Proximal femoral nail vs. dynamic hip screw in treatment of intertrochanteric fractures: a meta-analysis. Med Sci Monit 2014;20:1628-33. CrossRef

18. Korkmaz MF, Erdem MN, Disli Z, Selcuk EB, Karakaplan M, Gogus A. Outcomes of trochanteric femoral fractures treated with proximal femoral nail: an analysis of 100 consecutive cases. Clin Interv Aging 2014;9:569-74. CrossRef

19. Huang X, Leung F, Xiang Z, Tan PY, Yang J, Wei DQ, et al. Proximal femoral nail versus dynamic hip screw fixation for trochanteric fractures: a meta-analysis of randomized controlled trials. ScientificWorldJournal 2013;2013:805805. CrossRef

20. Parker MJ, Handoll HH. Replacement arthroplasty versus internal fixation for extracapsular hip fractures. Cochrane Database Syst Rev 2000;2:CD000086.

21. van Dortmont LM, Douw CM, van Breukelen AM, Laurens DR, Mulder PG, Wereldsma JC, et al. Cannulated screws versus hemiarthroplasty for displaced intracapsular femoral neck fractures in demented patients. Ann Chir Gynaecol 2000;89:132-7.

22. Karaman Ö, Özkazanlı G, Orak MM, Mutlu S, Mutlu H, Çalışkan G, et al. Factors affecting postoperative mortality in patients older than 65 years undergoing surgery for hip fracture. Ulus Travma Acil Cerrahi Derg 2015;21:44-50. CrossRef

23. Davison JN, Calder SJ, Anderson GH, Ward G, Jagger C, Harper WM, et al. Treatment for displaced intracapsular fracture of the proximal femur. A prospective, randomised trial in patients aged 65 to 79 years. J Bone Joint Surg Br 2001;83:206-12. CrossRef

24. Kapicioglu M, Ersen A, Saglam Y, Akgul T, Kizilkurt T, Yazicioglu O. Hip fractures in extremely old patients. J Orthop 2014;11:136-41. CrossRef

25. Johansson T, Jacobsson SA, Ivarsson I, Knutsson A, Wahlström O. Internal fixation versus total hip arthroplasty in the treatment of displaced femoral neck fractures: a prospective randomized study of 100 hips. Acta Orthop Scand 2000;71:597-602. CrossRef

26. Rogmark C, Carlsson A, Johnell O, Sernbo I. A prospective randomised trial of internal fixation versus arthroplasty for displaced fractures of the neck of the femur. Functional outcome for 450 patients at two years. J Bone Joint Surg Br 2002;84:183-8. CrossRef 
ORİJINAL ÇALIŞMA - ÖZET

\section{Femur intertrokanterik kırıklarının tedavisinde proksimal femur çivisi} ve hemiartroplasti sistemlerinin karşılaştırılması

\section{Dr. Gökay Görmeli, ${ }^{1}$ Dr. Mehmet Fatih Korkmaz, ${ }^{1}$ Dr. Cemile Ayşe Görmeli, ${ }^{2}$ Dr. Cihan Adanaş, ${ }^{3}$ Dr. Turgay Karataş, ${ }^{4}$ Dr. Sezai Aykın Şimşek ${ }^{5}$}

${ }^{1}$ Inönü Üniversitesi Tıp Fakültesi, Turgut Özal Tıp Merkezi, Ortopedi ve Travmatoloji Anabilim Dalı, Malatya

2̇̇nönü Üniversitesi Tıp Fakültesi, Turgut Özal Tıp Merkezi, Radyoloji Anabilim Dalı; Malatya

${ }^{3}$ Van Bölge Eğitim ve Araştırma Hastanesi, Ortopedi ve Travmatoloji Kliniği, Van

${ }^{4}$ Malatya Devlet Hastanesi, Genel Cerrahi Kliniği, Malatya

${ }^{5}$ American Hospital, Ortopedi ve Travmatoloji Kliniği, İstanbul

AMAÇ: Çalışmamızın amacı intertrokanterik femur kırığı olan yaşlı hastalarda proksimal femur çivisi (PFÇ) ve bipolar hemiartroplasti (BPH) ile tedavinin sonuçlarını karşılaştırmaktı.

GEREÇ VE YÖNTEM: Çalışmaya Ocak 2008-Ocak 2012 arasında femur intertrokanterik kırığı nedeni ile tedavi edilen I43 hasta dahil edildi. Hastaların demografik verileri; AO/ASIF (Association for Osteosynthesis/Association for the Study of Internal Fixation) sınıflamasına göre kırık tipi; ASA (American Society of Anesthesiologists) skorları; cerrahi yöntem (PFÇ veya BPH); cerrahinin detayları; komplikasyonlar ve takip sonuçları (Harris Kalça Skoru, Ortalama Hareketlilik Skoru) kaydedildi.

BULGULAR: Cerrahi öncesi veriler PFÇ ve BPH grubunda benzerdi. Bipolar hemiartroplasti grubunda cerrahi süresi daha uzun; cerrahi sırasındaki kan kaybı ve mortalite oranları daha yüksekti $(p<0.005)$. 30.4 ( I0.9) aylık takip sonucunda Ortalama Hareketlilik Skoru'ndaki azalma ve Harris Kalça Skoru'nda anlamlı fark yoktu ( $\mathrm{p}>0.05)$.

TARTIŞMA: Cerrahi tedavi uygulanan femur intertrokanterik kırıklı yaşlı hastalarda PFÇ ve BPH sonuçlarının her ikisi de tatmin edici olsada; daha az cerrahi ile ilişkili travma ve düşük mortalite oranları ile PFÇ'nin bu hastalarda daha etkili ve uygun tedavi yöntemi olarak tercih edilebileceğini düşünmekteyiz.

Anahtar sözcükler: Bipolar hemiartroplasti; femur intertokanterik kırı̆ı̆; Harris kalça skoru; mortalite; proksimal femur çivisi.

Ulus Travma Acil Cerrahi Derg 2015;2I(6):503-508 doi: 10.5505/tjtes.20I5.96I66 